\title{
MEANING AND UNDERSTANDING IN CONVERSATIONS: THE LISTENER'S CONTRIBUTION TO FACE-TO-FACE INTERACTION IN JAPANESE $^{1}$
}

Elisa Mie Nishikito

RESUMO: A conversação é um processo colaborativo através do qual falantes e ouvintes negociam conceitos e ações para alcançarem a compreensão mútua. Neste trabalho, enfocamos o comportamento verbal do ouvinte, como, por exemplo, os fáticos retroalimentadores, solicitação de esclarecimentos e retomada de conteúdos previamente apresentados, procurando mostrar o papel ativo que o ouvinte exerce para o sucesso da interação conversacional.

ABSTRACT: Conversation is a collaborative process through which participants negotiate ideas and actions in order to reach mutual understanding. In this paper we focus on the listener's verbal behavior, such as back channels, requests for clarification and restatements, and attempt to show that the listener plays an active role in the achievement of successful interactive conversation.

PALAVRAS-CHAVE: discurso conversacional, colaboração, ouvinte, compreensão. KEYWORDS: conversational discourse, collaboration, listener, understanding.

\section{Introduction}

There is an agreement that verbal face-to-face interaction is a result of collaborative actions by both speakers and interlocutors. "In conversation, people coordinate

1. This paper reports on some preliminary results of Ph.D. research concerning the "listener's verbal behavior in face-to-face interaction" conducted at the Department of International Communication of the Graduate School of International Development, Nagoya University, Japan. 
linguistically to produce mutually coherent structures insofar as this evidence helps them coordinate conceptually on the contribution to their discourse" (Wilkes-Gibbs, 1995: 266). In order to accomplish such a conversational goal, speakers and listeners make use of their cognitive and linguistic skills in combination with their socio-cultural knowledge.

Considering that conversation happens through a process of turn exchange, in which speaking and listening co-occur in real time, we believe that a study focusing on the listener's verbal production can contribute to clearing up some of the questions regarding the dynamics of coordinating mutual beliefs and actions in spontaneous performances.

As stated by Clark and Wilkes-Gibbs (1986: 3), there are three aspects that must be taken into account when we study actual conversations. "First, in conversation unlike writing, speakers have limited time for planning and revision. They need to overcome this limitation, and in doing so they may exploit techniques possible only in conversational settings. Second, speech is evanescent. The listener has to attend to, hear, and try to understand an utterance at virtually the same time it is being issued. That requires a type of process synchronization not found in reading. And third, listeners in conversations aren't mute or invisible during an utterance. Speakers may alter what they say midcourse based on what addressees say and do"

From the statement above, it is clear that the conversational text, which is linguistically structured, is a trace of the process through which discourse is produced. It is a process, but not a product, and therefore can be seen as an object that might help analysts to recover the discourse-building process.

In this paper we propose to make an analysis of the listener's utterances (such as back channels, asking for clarification and restatements) in order to discuss some implications with regard to how both processes and products of language use are modeled. In addition, we intend to reconsider the listener's role in conversation and show how active he is in the development of verbal interaction. Our point is that the listener not just coordinates his actions according to the 'mechanics' of interaction as proposed by the sociologists' view, but that he is a cognitively active individual, fulfilling his responsibility in a joint activity.

\section{Basic Concepts and Framework}

\subsection{Language, cognition and social interaction}

In recent years, work from a number of disciplines has been converging on the recognition that there are deeply embedded, reciprocal relations among language, cognition, and social interaction. Marcuschi (1998:16), in his work on "comprehension activities in verbal interaction", takes the following assumptions as the basis for his analysis.

a. Language is not an autonomous instrument for codification, production and transmission of meaning; and meaning is not objective, nor has it a single 
significance clearly inscribed in the text. Although language presents a certain stability, it is an activity which is contextually situated, cognitively determined and socially and historically constituted;

b. The oral or written text is more a discoursive event rather than a meaningful unit (Beaugrande: 1997) and verbal interaction whether realized either within or out of a conversational structure is a semantic activity, i.e., verbal interaction is a space where meaning is created;

c. Conversational coherence is not a product of a simple relation between contents linearly connected; it is built through multiple guided efforts to coordinate actions, so that meaning arises as a result of lexico-grammatical processes, collaborative processes and mutual suppositions;

d. Coordination and synchronization of actions, such as sequencing ideas or coordinating rhythm (synchrony in prosody), contribute in a decisive way to create 'spaces' and 'opportunities' for meaning. It makes the quality of coordination relevant as a source of meaning and as a basis for understanding or misunderstanding;

e. Negotiation and joint production are essential activities for the production of meaning in any socio-communicative encounter in which two or more individuals are engaged and have as one objective mutual understanding.

From the statements above, we can notice that conversation is a collaborative process through which participants negotiate and coordinate actions and ideas in order to construct meaning. This makes cognition a fundamental element for understanding verbal interaction. Marcuschi (1998) acknowledges its importance, but at the same time he views cognition from an 'interactionist' approach which emphasizes that mutual understanding also depends upon moment by moment interaction between particular speakers and hearers located in socio-cultural space and time. We share the same opinion as Marcuschi, and based on the assumptions listed above, we will attempt to reflect upon how listeners coordinate their participation with speakers at the level of both content and actions, by combining both understanding and collaborative participation.

\subsection{Literature review on the listener's participation in conversation}

During the last two or three decades, many studies directly or indirectly concerning the listener's participation in conversation have been developed in several different areas. Yngve (1970) wrote a pioneer work in linguistics, which presents a distinction between speakers and listeners and an analysis of back channels. The biggest contribution to the study of the listener's behavior, however, comes from work developed within Sociology and related areas (Duncan: 1973, 1974, 1977, 1985; Goffman: 1976; Goodwin: 1981; Scheggloff: 1982). More recently, with the advance of pragmatics and the cognitive approach, work concerning misunderstanding in communication (House: 1993) and discourse organization based on language processing models (Edelsky: 1981; Hayashi: 1996; Clark \& Wilkes-Gibbs:1986; Wilkes-Gibbs:1995; Coats:1995) have also focused on the listener's participation in interaction. 
Most of the studies cited above have focused on features of the listener's behavior determined in advance. Phenomena such as back channel behavior or responses to questions (Pomerantz: 1984) have been the focus of analysis and, by extension, they have been interpreted as studies concerning the listener's behavior. However, except for the work of Duncan, each of them targets one aspect (verbal or non-verbal) that is thought to belong or be related to the listener, and cannot be said to constitute an actual study on the listener's behavior.

In Japan, similarly to what was described above, several scholars have focused on the study of back channels (Mizutani: 1983, 1988a, 1988b; Matsuda: 1988; Sugito: 1989; Maynard: 1987, 1993), but almost none makes reference to the listener's behavior in its entirety. An exception is Horiguchi (1997), who broadens the focus, establishes a distinction between speaker and listener, and presents a list of functional structures that, according to her, characterizes the listener's behavior. One limiting aspect of Horiguchi's work is that she conducts her analysis within the framework of the ethnomethodologists and interprets the results within structural and interactional properties of conversation.

Our aim, as previously explained, is to make a study of the listener's verbal behavior, not restricted to the study of back channels, within a broader theoretical framework that includes the pragmatic and social aspects of interaction, as well as the recent contributions from studies developed within a cognitive approach.

\subsection{Concept of floor as a criteria for defining the "listener"}

Before we proceed with the analysis of the listener's verbal behavior, it is important to make clear the concept of listener used in this paper. To this end, we will make use of the concept of floor, proposed by Edelsky (1986) and further extended by Hayashi $(1996)^{2}$. Floor happens "within a psychological time and space" (Edelsky, 1986: 405) and "is a cognitive entity that the interactants jointly create during the course of a conversation" (Hayashi, 1996:31). The term 'psychological time' refers to the fact that turns of the speaker who has the floor can be separated in real time by another turn as shown in the example below. Here, Gs' turns are interrupted by Hf's turn.

Gs: Iryô saiban ni wa mittsu no kabe ga gozaimashite (Hf: hai) e: dai ichi no kabe ga senmonsei no kabe nandesune (Mf: ha) e: igaku iryô no koto wa kôdo no senmonteki na sekai no koto nano de watashitachi mo benkyô shinakya to iu koto desu

Hf:

[bengoshi no sensei gata
Gs: In medical trials there are three obstacles (Hf: yes) uh the first one is the obstacle of specialization right (Hf: uhh) uh medicine is a world of high specialization so it means that we also have to study

Hf:

[even for lawyers you

mean

Gs: yes of course uh well several [...] ni tottemo to iu

Gs: mochiron sôdesu e: ano iroiro to [...]

2. We believe that the concept of floor can account for the cognitive aspects of interaction, instead of 'turn' 
With respect to 'psychological space', Edelsky (1986) means that it is possible to have the floor while not talking. In the example given, even if Gs kept silent for a while (in order to organize his ideas, for example) during the explanation, Hf would still know that Gs was the one in charge of the conversation.

In this paper, taking the concept of floor as the basis for our study, we will consider as listener the participant who does not hold the floor. Therefore, any comment, request for clarification, restatement, interruption, back channels, etc. of a non-floor holder will be considered as part of the listener's behavior.

\section{Methodology}

\subsection{Data}

Our preliminary report on the listener's verbal behavior is based on an analysis of a multi-party conversation presented in a TV program. It was first video-taped and then transcribed. In the conversation, six participants (two hosts, one reporter, and three guests) interacted to discuss deaths caused by medical malpractice and legal measures taken in such cases. The program took one hour, but we restricted the transcription and the analysis to 16 minutes, since that was the actual time spent by participants in discussing the topic.

The letters of the alphabet used to indicate the participants as well as the symbols used in the transcription are as follows:

\begin{tabular}{|c|c|c|}
\hline \multicolumn{3}{|c|}{ Data recorded on April 14, 1999} \\
\hline Participants: & $\begin{array}{l}\text { Hf = host (woman) } \\
\text { Hm = host (man) } \\
\mathrm{R}=\text { reporter } \\
\text { Gs = guest (specialist) } \\
\text { Gf = guest (woman) } \\
\text { Gm = guest (man) }\end{array}$ & $\begin{array}{l}\text { Symbols used in the transcription: } \\
\begin{array}{ll}{[\quad=} & \text { speech overlap } \\
: & =\text { lenghtened sounds } \\
() \quad= & \text { pause } \\
I & =\text { brief interruption in the } \\
& \text { utterance }\end{array}\end{array}$ \\
\hline
\end{tabular}

In multi-party conversations such as the one used in this study, hosts have some particular characteristics that distinguish them from other participants. They have the right to interfere at any time in the course of the on-going talk to give comments, change the topic, allocate the turn from the current speaker to another participant; this gives them authority over the others. On the other hand, in order to fulfill this duty, hosts have to be attentive to everything that is being said so that they can take the necessary and adequate actions, at the right moment. For this reason, i.e., because hosts are cognitively attentive in the course of the conversation, we will focus our

which is a widely used term, but a rather technical or mechanical concept, and therefore insufficient for our purposes. For more information about the distinction between 'turn' and 'floor' see Edelsky (1986). 
analysis on the verbal behavior of hosts ( $\mathrm{Hf}$ and $\mathrm{Hm}$ ) when they are non-floor holders, and therefore play the role of listeners.

\subsection{Theoretical Framework}

Since our objective in this paper is to study the listener's verbal behavior in conversation and how it contributes to face-to-face interaction by allowing participants to negotiate meaning to achieve mutual understanding, we will carry out our analysis within the framework of collaborative processes approach.

This perspective comes from recent works that focus on collaborative processes in language use and argue that meaning in communication is a social construction, both implicitly and explicitly (Wilkes-Gibbs, 1995: 239). According to this view, meaning and by extension, coherence and understanding arise from a collaborative process by which participants, moment-by-moment, negotiate and coordinate actions and ideas. Meaning and understanding are, therefore, a collective process and, at the same time, a social event.

This approach seems adequate for our purposes to account for intra and extratextual elements of language, as well as for the cognitive aspect involved in interaction. According to our view, conversational text encompasses relationships between linguistic elements within a stream of speech, but at the same time we see these linguistic elements that constitute utterances as context-bound, which means that features of context must be taken into consideration when we study conversation. Finally, we also acknowledge that there are some mental processes put in action by participants that produce evidence of a shared understanding.

\section{Analysis of Listener's Verbal Behavior in Face-to-face Interaction}

Consider the following excerpt, in which Gs (a lawyer specializing in civil suits against medical malpractice) as the floor-holder, is explaining how frequent medical/ doctor negligence is in Japan.

01 Gs: e: ano: nennen fuete wa kite imausuga Hf:

Gs: ah saiban ni naru no wa ah yoku yoku no koto de arimashite e: hyôzan no mô $05 \mathrm{Hm}$ : I hai

Gs: hontô ni goku ah teppen no mono da to omoimasu (Hf: hai) sono hokani e: jidan ni kaigi tsukutte to iu no mo gozaimasu kedomo nakineiri desu ne ima

$10 \mathrm{Gf}$ : [ $\mathrm{mhm}$

Gs: osshatta nakineiri sareru kata ga takusan irasshaimasushi

$H f: m h m$
Gs: uh well it has grown every year but

Hf: [yes

Gs: uh cases that go to court are uh for unavoidable reasons and uh I think

Hm: [yes

they are extremely few on tip of the iceberg (Hf: yes) in addition uh there are meetings held in private but people give up in the end you see as

Gf: [uhn

Gs: you just mentioned there are many people who give up Hf: uhn 
Gf: [mhm

15 Gs: somo somo iryô jiko ni atta to iu koto wo kizukanai to iu kêsu mo arimasu ne tatoeba Hm: $\quad$ Imhm

Hf: $\quad$ Tha

Gs: kôganzai nanka de e: nakunattemo gan de

20 shinjattanda to omotte iru hito ga takusan iru to omoimasu

$\begin{array}{ll}H f: & \text { Iha } \\ \text { Gf: } & \text { [mhm }\end{array}$

Hf: tada ima jidan to osshaimashita keredomo

25 Gs:

Hf: jidan to wakai wa dô chigaimasuka

Gs: e: ano: saiban wo okosu mae ni hanashiai de kaiketsu shite iru no o jidan to watashitachi wa iimasu de saiban o

30 okoshite kara e: hanashiai de saiban de kaiketsu tsuku mono o wakai to yonde orimasu

$\mathrm{Hm}$ : [ $\mathrm{mhm}$

Hf: $\quad$ [a: naruhodo saiban ni

35 itaranai kedo ôku no misu/a/kôiu koto ga $\mathrm{Hm}$ : I $\mathrm{mhm}$

Hf: okotteiru kamo shirenai

Hm: hai

Gs: sôdesune

$40 \mathrm{Hf}$ : hai
Gf: [uhn

Gs: to begin with people do not notice that there has been medical negligence

$\mathrm{Hm}$ :

[uhn

Hf:

[uhh

Gs: for example although someone died because of an anti-cancer drug there might be many people who think that he/she died of cancer

Hf: [uhh

Gf: [uhn

Hf: but you just mentioned private settlement

Gs: [yes

Hf: what is the difference between private settlement and peaceful settlement

Gs: uh well before going to court when the problem is solved in private we call it private settlement and once taken to court uh when the problem is solved in negotiations at court we call it peaceful settlement

Hm: [uhn

Hf:

[I see they are not taken

to court but there might be a lot of mis/a/things like that happening

Hm: [uhn yes

Gs: that is right

Hf: yes

During Gs' talk the following behavior related to the listener could be identified:

a. back channels such as hai "yes", $e$ : "yes", ha "uhh", $m h m$ "uhn" that were produced by the listeners Hf and Hm;

b. asking for a clarification such as the question made by Hf: tada ima jidan to osshaimashita keredomo jidan to wakai wa dô chigaimasuka "but you just mentioned private settlement what is the difference between private settlement and peaceful settlement";

c. restatement such as the one made by Hf: saiban ni itaranai kedo ôkuno misu/a/kô iu koto ga okotteiru kamo shirenai "they are not taken to court but there might be a lot of mis/a/things like that happening"

\subsection{Back channels}

With respect to back channels, there were plenty of them during the course of Gs's explanation. Schegloff (1981: 80) called such back channels "continuers" and 
according to him, these elements show that the listener is paying attention to the speaker's talk and that the former acknowledges that the latter is in the middle of the extended unit of talk. In addition, Schegloff stated that by producing such back channels the listener passes up the opportunity to initiate a repair on the turn so far and, by implication, indicates that he understood what was said up to that moment in the conversation.

However, we can notice from Hf's question about the difference between jidan "private settlement" and wakai "peaceful settlement", that she had not completely understood the explanation of Gs. Her back channels during the course of Gs"s talk signaled that she was paying attention to what was being said by Gs, but also that she was uncertain of the meaning of his words, as if saying: "I am listening, please go on with your explanation"

The example above shows that it is a fact that back channels express the listener's attention to the on-going talk. However, they do not necessarily imply understanding.

With respect to Hm's productions, we cannot say, for sure, if his back channels signal attention and also understanding. He might not have understood Gs's production as Hf did not, and still might have produced back channels just to let the speaker go on with his talk. Therefore, back channels might be used by the listener to signal attention, both attention and understanding or to 'deceive' the speaker who is currently talking, by claiming understanding when there is none.

\subsection{Request for clarification}

In the excerpt above, by asking the question in line 24-26, Hf first displays nonunderstanding about a specific term used by Gs (jidan), and asks for an extra explanation, before Gs or another participant in conversation go on to the next contribution.

According to Clark and Wilkes-Gibbs (1986:9), "conversations proceed in a orderly way only if the common ground of the participants accumulates in a orderly way" They mean that speaker and listener must establish the mutual belief that the listener has understood, or appears to have understood the speaker's current utterance, before they go to the next contribution.

In the example given, because of Hf's question, Gs who had mentioned very briefly the word jidan, in line 07 , had to pick up the word again and expand his utterance by explaining the meaning of jidan and wakai, until the listener signaled that she had understood.

In our data, in addition to a request for clarification due to the listener's lack of understanding, we found other types of request. The listener made a question to confirm some word or content presented by the speaker; or asked a question introducing a new topic because the speaker's previous utterance made him/her remember something else that was directly or indirectly related to the current topic. In the former case, the speaker answered the listener's request with a confirmation, and in the latter case, by answering the listener's question, the speaker introduced a new topic into the conversation. 
In both cases, questioning was revealed to be an important device used by participants to check each other's understanding concerning the current topic or content previously presented, thus allowing conversation to advance.

\subsection{Restatements}

We call restatements the listener's production that recovers part or all the content expressed by the speaker in the previous utterance. Looking at the excerpt presented above, we notice that Hf's utterance in line 34 ( saiban ni itaranai kedo ôku no misu/ a/kô iu koto ga okotteiru kamo shirenai " they are not taken to court but there might be a lot of mis/a/things like that happening "), restates with different words what Gs said at the beginning of his talk (lines 04-06): saiban ni naru no wa ah yoku yoku no koto de arimashite e: hyôzan no mô hontô ni goku ah teppen no mono da to omoimasu "cases that go to court are uh for unavoidable reasons and uh I think they are extremely few on the tip of the iceberg". Hf actually understood the meaning of Gs's utterance only after his explanation about 'private settlement' and 'peaceful settlement'

As we previously described, in face-to-face interaction, listeners have to interpret an utterance at almost the same time it is produced by the speaker. The heavier burden usually falls on the listener who has to interpret both the linguistic message and the speaker's intentions. Restatements, then, as well as repetition, are more than just redundancy. They are features used by listeners to assert understanding.

\section{Discussion and Further Implications}

In this paper we focused on the listener's verbal behavior in order to investigate how his participation contributes to the process of constructing meaning and mutual understanding in face-to-face interaction.

Meaning and understanding, as observed earlier, result from a process of negotiation between speaker and listener and can extend for several turns. The participants, if necessary, repair, expand, replace linguistic structures in an iterative process until they reach a version they mutually accept.

In our data, we observed that during the course of Gs's talk, the listeners $\mathrm{Hf}$ and Hm produced back channels that allowed the speaker to continue his utterance. From the speaker's point of view, back channels might have been interpreted as "continuers", since the speaker continued talking whenever he received feedback signals from the listener. However, from the listener's point of view, we observed that these elements signaled simply attention or both attention and understanding. In addition, we observed that they could be used to deceive the speaker, if the listener is only pretending to understand.

Broadly speaking, back channels produced in interaction are devices that allow the conversation to develop. Since ideal understanding between participants is impractical, listeners tacitly accept the speaker's contribution to the extent that their acceptance will not break the conversation. By sending back channels, and allowing 
speaker to continue, listeners trust that holes will be filled in later, or that they will not have serious consequences.

When holes are not filled, they ask questions. In the data we found not only requests for clarification due to the listener's lack of understanding, but also a request for confirmation or a question functioning to introduce a new topic. All cases were interpreted not as breaks or interruptions, but as opportunities to make clear that participants shared the same ground so that they could proceed to the next contribution.

Similarly, restatements were interpreted as features that expressed the listener's strong engagement for recovering both semantically and linguistically what the speaker said.

In this preliminary study, we limited our analysis to three phenomena: back channels, requests for clarification and restatements. However, there are others such as making comments and making interruptions during the course of the speaker's talk, that are part of the listener's behavior but were not focused in this paper. In addition, by carrying out this analysis it became clear that the negotiation of meaning and understanding at the level of content has significant consequences for the linguistic structure of conversational discourse, for the participation structure and for the cognitive processes of individual members. We propose, then, to investigate these aspects in the near future.

\section{References}

CLARK, Herbert H. \& WILKES-GiBBS, Deanna. "Referring as a collaborative process". Cognition. Vol. 22, Number 1, 1986, pp. 1-39.

COATS, Jennifer. "The negotiation of coherence in face-to-face interaction: some examples from the extreme bounds" In: GERNSBACHER, Morton A. \& GIVÓN, Talmy (ed.). Coherence in spontaneous text. Amsterdam/Philadelphia, John Benjamins, 1995, pp. 41-58.

DUNCAN, Starkey. "Towards a grammar for dyadic conversation". Semiotica. Vol. 9, 1973, pp. 29-46.

. "On the structure of speaker-auditor interaction during speaking turns" Language in Society. Vol. 2, 1974, pp. 161-180.

DUNCAN, Starkey \& FISKE, Donald. Face-to-face interaction: research, methods and theory. Hillsdale, NJ, Earlbaum, 1977.

Interaction structure and strategy. Cambridge/Paris, Cambridge University Press/ La Maison des Sciences de l'Homme, 1985.

EDELSKY, Carole. “Who's got the floor?”, Language in Society. Vol. 10, 1986, pp. 383-421.

GoFFMAN, Erving. "Replies and responses" Language in Society. Vol. 5, 1976, pp. 257-313.

GoodwIN, Charles. Conversational organization: interaction between speakers and heares. New York, Academic Press, 1981.

HAYASHI, Reiko. Cognition, Empathy, and Interaction: Floor management of English and Japanese Conversation. Volume LIV in the series Advances in Discourse Processes. Norwood, Ablex, 1996.

HoRIGUCHI, Sumiko. Nihongo kyôiku to kaiwa bunseki (The teaching of Japanese Language and Conversation Analysis). Tokyo, Kuroshio, 1997. 
HOUSE, Juliane. "Toward a model for the analysis of inappropriate responses in native/nonnative interactions". In: KASPER, Gabriele \& BLUM-KULKA, Shoshana. Interlanguage Pragmatics. New York/ Oxford, Oxford University Press, 1993, pp. 161-183.

MARCUSCHI, Luiz Antônio. "Atividades de Compreensão na Interação Verbal" (Comprehension activities in verbal interaction). In: PRETI, Dino (ed.). Estudos da Lingua Falada: Variações e Confrontos (Studies of Spoken Language: variations and confrontations). São Paulo, Humanitas/FFLCH/USP, 1998, pp. 15-46.

MATSUDA, Yôko. "Taiwa no nihongo kyôiku: aizuchi ni kanren shite" (The teaching of Japanese as dialogue: regarding back channels). Nihongogaku (Studies of Japanese Language). Vol. 7, Number 12, 1988, pp. 59-66.

MAYNARD, Senko. "Nichibei kaiwa ni okeru aizuchi hyogen" (Back channel expressions in Japanese and English conversations). Gengo (Language). Vol. 16, Number 1, 1987, pp. 88-92.

Kaiwa Bunseki (Conversation Analysis). Tokyo, Kuroshio, 1993.

MizUTANI, Nobuko. "Aizuchi to han'nô" (Back channels and responses). Kôza nihongo no hyôgen 3 / Hanashi kotoba no hyôgen (Course of Japanese Expressions 3/Expressions of spoken language). Tokyo, Chikuma shobô, 1983, pp. 37-44.

"Hanashi kotoba no hikaku taishô" (Contrastive study of spoken language). Nihongo kyôshi yô sankôsho 2 / Hanashi kotoba to communication (Manual for teachers of Japanese Language 2 / Spoken language and communication). Tokyo, Bonjinsha, 1988a, p.86-108.

"Aizuchi ron" (Theory of back channels). Nihongogaku (Studies of Japanese Language). Vol. 7, Number 12, 1988b, pp. 4-12.

PomeranTZ, Anita. "Pursuing a response". In: Atrinson, J. Maxwell \& Heritage, John. Structures of social action: studies in conversation analysis. Paris/Cambridge, Maison de Sciences de l'Homme/Cambridge University Press, pp. 152-164.

SCHEGLOFF, Emanuel A. "Discourse as an interactional achievement: some uses of 'uh huh' and other things that come between sentences". In: TANNEN, Deborah (ed.). Georgetown University Roundtable on Language and Linguistics. Washington, D.C., Georgetown University Press, 1982, pp. 71-83.

SUGITO, Seiju. "Kotoba no aizuchi to miburi no aizuchi" (Verbal back channels and non-verbal back channels). Nihongo kyôiku (The teaching of Japanese Language). Vol. 67, 1989, pp. 48-59.

WILKES-GIBBS, Deanna. "Coherence in collaboration: some examples from conversation" In: GernsBaCher, Morton A. \& Givón, Talmy (ed.). Coherence in spontaneous text. Amsterdam/Philadelphia, John Benjamins, 1995, pp. 239-267.

YNGVE, V. H. "On getting a word in edgewise" Chicago Linguistics Society. Vol. 6, 1970, pp. 567-578. 